(3) When the benzene solution of the yellow $\alpha$-naphthoquinone (IV) is exposed to sunlight, the photo-dimer (V) is formed, insoluble in aqueous alkali. The substance, colourless crystals m.p. about $244^{\circ}$ (decomposition), forms IV on heating (found : $\mathrm{C}, 75 \cdot 7 ; \mathrm{H}, 4 \cdot 1 . \mathrm{C}_{20} \mathrm{H}_{12} \mathrm{O}_{4}$ requires $\mathrm{C}, 75 \cdot 9 ; \mathrm{H}, 3 \cdot 8$ per cent). (V) is of interest as its enol form ( $\mathrm{V} a$ ) is related to the biphenylene (VI) much discussed at present.

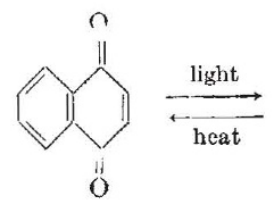

(IV)

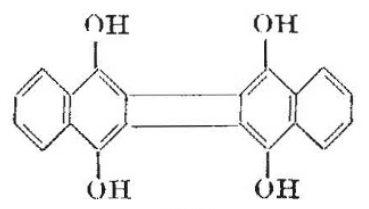

$(\mathrm{V} a)$
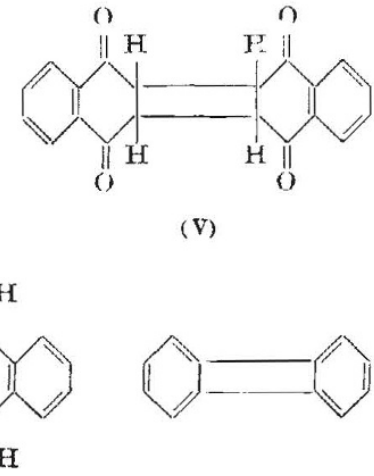

(V)

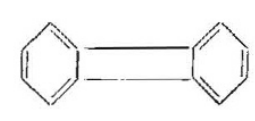

(VI)

ALEXANDER SchöNBERG

AHMEn Mustaka

Mohamed ZaKi Barakat

Fouad I University,

Faculty of Science,

Abbassia, Cairo.

May 17.

'Nature, 153, 195 (1944). J. Chem. Soc., 67, 387 (1944); 55I, 657 (1945).

${ }^{2}$ Comp. Shmuk and Guseva, Amer. Chem. Abstr., 35, 3271 (1941).

${ }^{3}$ Comp. Guyot and Catel, Bull. Soc. chim., (3), 35, 1127 (1906); and Adams and Gold, J. Amer. Chem. Soc., 62, 2041 (1940).

\section{Oxidation of Olefins by Chromic Acid}

THE oxidation of $2: 4: 4$-trimethylpentene-1 [ $\alpha$-diisobutylene] [I] by chromium tri-oxide dissolved in acetic anhydride yields a neutral oil containing largely $2: 4: 4$-trimethylpentan-1 : 2-epoxide [II] with smaller amounts of $2: 2$-dimethylpentanone-4 [V], 2:4:4-trimethylpentanal [III] with $2: 4: 4$ trimethylpentan-1 : 2-diol [IV] and unsaturated alcohols partly as acetates.

$2: 4: 4$-Trimethylpentene-2 [VI] behaves similarly to give the corresponding epoxide [VII] and other produets.

$$
\begin{gathered}
\mathrm{Me}_{3} \mathrm{C}_{2} \mathrm{CH}_{2} \cdot \mathrm{CHMe} . \mathrm{COOH} \leftarrow \mathrm{Me}_{3} \mathrm{C} \cdot \mathrm{CH}_{2} \cdot \mathrm{CHMe} \cdot \mathrm{CHO} \\
{[\mathrm{VI}]} \\
\mathrm{Me}_{3} \mathrm{C} \cdot \mathrm{CH}_{2} \cdot \mathrm{CMe}: \mathrm{CH}_{2} \rightarrow \mathrm{Me}_{3} \mathrm{C} \cdot \mathrm{CH}_{2} \cdot \mathrm{CMe} \cdot \mathrm{CH}_{2}
\end{gathered}
$$

$\mathrm{Me}_{3} \mathrm{C} \cdot \mathrm{CH}_{2} \cdot \mathrm{CO} \cdot \mathrm{CH}_{3} \leftarrow \mathrm{Me}_{3} \mathrm{C} \cdot \mathrm{CH}_{2} \cdot \mathrm{C}(\mathrm{OH}) \mathrm{Me} \cdot \mathrm{CH}_{2}(\mathrm{OH})$

[V]

[IV]

The most likely explanation of these observations is that the first stage of the oxidation by chromium tri-oxide in acetic anhydride is the epoxide [II]. If this assumption is accepted and extended to the oxidation of the olefin by chromic acid in aqueous sulphuric acid, this reaction can bo considered as dependent on the course of the hydrolysis of the epoxide [II] by the aqueous sulphuric acid, followed by the oxidation of the hydrolysis products by the chromic acid. This permits a satisfactory explanation of the formation of $2: 4: 4$-trimethylpentanoic acid [IV $]^{1,2}$ in the oxidation of $\alpha$-diisobutylene by an aqueous sulphuric acid solution of chromic acid, since it is now found that the epoxide [II] on treatment with aqueous sulphuric acid yields not only the glycol [IV] and unsaturated alcohols, but also $2: 4: 4$ trimethylpentanal [III]. Oxidation of this aldehyde yields the acid [VI], while neopentyl methyl ketone [V] arises from the oxidative fission of the glycol [IV].

Similarly, this hypothesis requires that $2: 2: 3: 3$ tetramethylbutanoic acid [IX] should be present in the oxidation products of $2: 4: 4$-trimethylpentene-2 or of technical dissobutylene, which contains about 20 per cent of this olefin. This acid should arise from the oxidation of the aldehyde [VIII], which is known to be formed in small yield from 2:4:4-trimethyl-

\begin{tabular}{|c|c|c|}
\hline $\begin{array}{c}\mathrm{Me}_{3} \mathrm{C} . \mathrm{CMe}_{2} \cdot \mathrm{COOH} \\
{[\mathrm{IX}]}\end{array}$ & $\leftarrow$ & $\begin{array}{r}\mathrm{Me}_{3} \mathrm{C} . \mathrm{CMe}_{2} . \mathrm{CHO} \\
\uparrow \quad[\mathrm{VIII}]\end{array}$ \\
\hline $\begin{array}{c}\mathrm{Me}_{3} \mathrm{C} \cdot \mathrm{CH}: \mathrm{CMe}_{2} \\
{[\mathrm{VI}]}\end{array}$ & $\rightarrow$ & $\mathrm{Me}_{3} \mathrm{C} . \mathrm{CH} \cdot \mathrm{CMe}_{2}$ \\
\hline $\mathrm{Me}_{3} \mathrm{C} . \mathrm{CHO}$ & - & $\mathrm{Me}_{3} \mathrm{C} \cdot \mathrm{CH}(\mathrm{OH}) \cdot \mathrm{C}(\mathrm{OH}) \mathrm{Me}$ \\
\hline
\end{tabular}
pentan-2 : 3-epoxide [VII] by the action of aqueous sulphuric acid ${ }^{3}$.

A search for this acid in the products of the oxida. tion of technical dissobutylene has now shown that it is indeed present in small amounts.

The anomalies recorded in the literature for the oxidation of olefins by chromic acid in aqueous sulphuric acid find a satisfactory and simple explanation on the basis of the hypothesis indicated here. Thus ethylene is reported to give some acetaldehyde and acetic acid ${ }^{4,5}$, dineopentylethylene $\left(\mathrm{C}_{12} \mathrm{H}_{24}\right)$ gives some dineopentylacetic acid, $\mathrm{C}_{12} \mathrm{H}_{24} \mathrm{O}_{2}{ }^{8}$; a small yield of an octanoic acid from octene is reported?. In the same category must be included the formation of trimethylacetic acid from tetramethylethylene ${ }^{8}$.

On this hypothesis one may also predict, from a knowledge of the behaviour of the epoxides in diluted sulphuric acid, what olefins should yield abnormal products on oxidation with chromic acid in aqueous sulphuric acid.

A full account of this work will be published else. where, and its extension on the lines indicated in this communication is in progress. Acknowledgment is made of the financial assistance afforded by the Institute of Petroleum, and also to Prof. F. H. Garner for providing facilities and accommodation for this work.

$$
\begin{aligned}
& \text { A. Byers } \\
& \text { W. J. Нiскгпвоттом } \\
& \text { Department of Chemical Engineering, } \\
& \text { University, Birmingham } 15 . \\
& \text { June } 17 .
\end{aligned}
$$

${ }^{1}$ Butleroff, Ann., 189, 44 (1877).

Homeyer, Whitmore and Wallingford, J. Amer. Chem. Soc., 55, 4211 (1933).

${ }^{3}$ Hickinbottom, Nature, 159, 844 (1947).

' Berthelot, Ann., 150, 373 (1869).

Zeidler, Ann., 197, 246 (1879).

- Whitmore and Surmatis, J. Amer. Chem. Soc., 83, 2200 (1941).

'I'reibs and Schmidt, Ber., 61, 462 (1928).

B Butleroff, J. Russ. Phys. Chem. Soc., 11, 210 (1879). 